Jpn. J. Med. Sci. Biol., 44, 99 - 108, 1991.

\title{
ANISAKIDAE LARVAE FOUND IN MARINE FISHES AND SQUIDS FROM THE GULF OF TONGKING, THE EAST CHINA SEA AND THE YELLOW SEA
}

Shizheng SUN, Tsutomu KOYAMA1 and Noboru KAGEI1*

Department of Parasitology, Shanghai Railway Medical College, Gong He Xin Road, Shanghai, The People's Republic of China and 1Department of Parasitology, National Institute of Health, Kamiosaki, Shinagawa-ku, Tokyo 141

(Received May 20, 1991. Accepted July 25, 1991)

SUMMARY: Marine fishes and squids caught in the Gulf of Tongking, the East China Sea and the Yellow Sea were dissected, and many Anisakidae larvae were found in them. The larvae of Anisakis simplex (Anisakis Type I larvae), the most important causative agent of anisakiasis, was found in about $30 \%$ of fishes and squids caught in the Gulf of Tongking and in about $60 \%$ of those caught in the East China Sea and the Yellow Sea. Larvae belonging to three other genera than Anisakis - Raphidascaris or Raphidascaroides, Hysterothylacium, and Terranova (Cannon Type I) - were also detected.

\section{INTRODUCTION}

Since Van Thiel (1) reported the discovery of ascaridoid nematode larvae of genus Anisakis (Anisakidae, Nematoda) in a patient suffering from acute abdominal pain and the worms were found to be a causative agent of this

孫 世正 (上海鉄道医学院 上海市共和新路 1238 号、中華人民共和国)

小山 力・影井 昇 (国立予防衛生研究所寄生虫部)

*Reprint requests to Dr. Noboru Kagei, Department of Parasitology, National Institute of Health, Kamiosaki, Shinagawa-ku, Tokyo 141, Japan. 
syndrome, many biological studies on Anisakidae have been conducted throughout the world, especially in Japan (2-9).

In China, however, little has been studied on the parasite, with only exceptions of the work by Hsu et al. (10) and by one of the present authors $(11,12)$. One of the latter two reports also dealt with the investigation on Anisakidae larvae found in marine fishes and squids, but it was preliminary and incomplete (11). Therefore, the present authors intended to advance their work to clarify the state of Anisakis infection among fishes captured off the Chinese continent and to gather basic knowledge on human anisakiasis.

\section{MATERIALS AND METHODS}

Marine fishes and squids captured in the East China Sea and the Yellow Sea were provided by Shanghai Marine Fishery Company between March and July, 1985, and those captured in the Gulf of Tongking by Guangzhou Marine Fishery Company during December, 1986.

The fishes and squids were measured for the body weight and length and they were dissected to detect Anisakidae larvae. The collected larvae were fixed with a heated $70 \%$ ethanol solution and cleared as usual with a $70 \%$ ethanol/glycerine mixture (9:1). The morphological features of the worms were observed under a microscope, and the size of each organ of the worms was measured. The worms were identified from their morphological characteristics.

\section{RESULTS}

Anisakidae Larvae Found in Marine Fishes and Squids Captured in the Gulf of Tongking

Thirty-one species of marine fishes and squids were investigated for the presence of Anisakidae larvae. The detected Anisakis simplex larvae (Anisakis Type I larvae) were measured and morphologically examined (Table I). The larvae were identified from the morphological data obtained in reference to the standard published by Koyama et al (2).

In 15 species of fishes tested, the infection with Anisakis simplex larvae was found (Table II). The number of fishes and squids examined was 140, and the number of those infected with the larvae 41 . The infection rate was $29.3 \%$. 


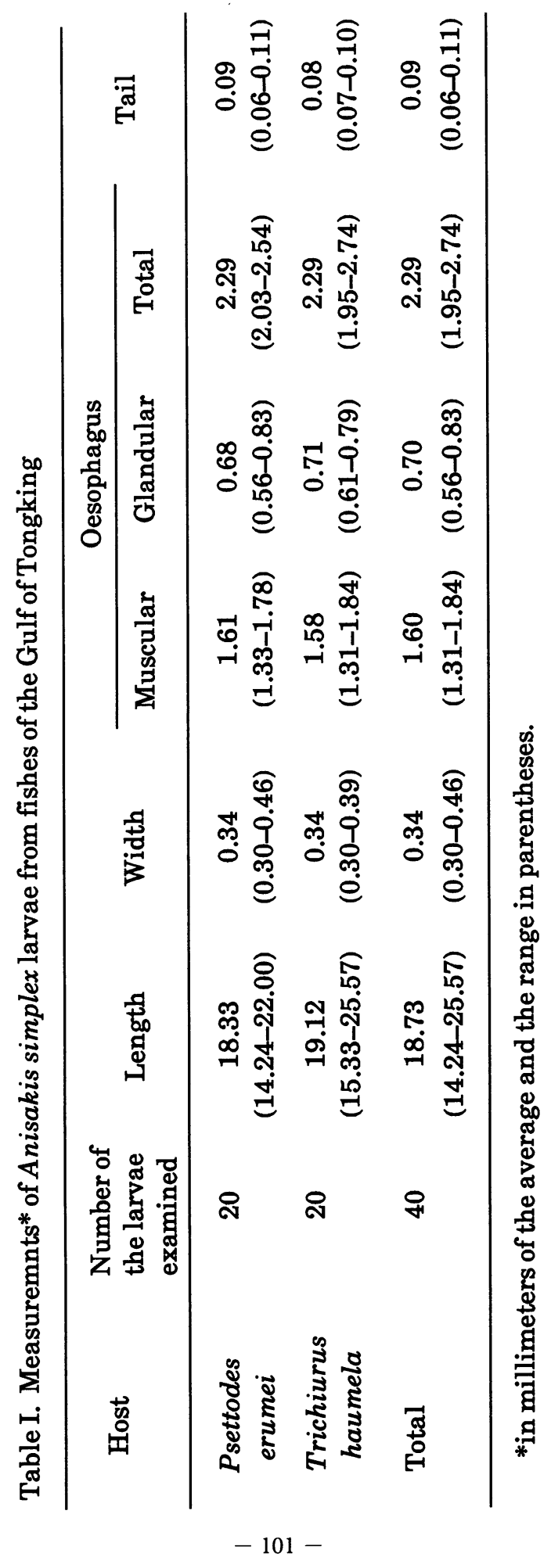


Table II. Anisakidae larvae from various fishes and squids caught in the Gulf of Tongking

\begin{tabular}{|c|c|c|c|c|}
\hline Host & $\begin{array}{l}\text { Number } \\
\text { examined }\end{array}$ & $\begin{array}{l}\text { Number of } \\
\text { fishes and } \\
\text { squids } \\
\text { infected with } \\
\text { Anisakis } \\
\text { simplex } \\
\text { larvae }\end{array}$ & $\begin{array}{l}\text { Infec- } \\
\text { tion } \\
\text { rate } \\
(\%)\end{array}$ & $\begin{array}{l}\text { Anisakidae } \\
\text { larvae of } \\
\text { other than } \\
\text { Anisakis } \\
\text { simplex }\end{array}$ \\
\hline $\begin{array}{l}1 \text { Priacanthus tayenus } \\
2 \text { Muraenesox cinereus } \\
3 \text { Decapterus maruadsi } \\
4 \text { Branchiostegus argentatus } \\
5 \text { Trichiurus haumela } \\
6 \text { Saurida elongata } \\
7 \text { Epinephelus areolatus } \\
8 \text { Lutjanus sebae } \\
9 \text { Psettodes erumei } \\
10 \text { Therapon jarbua } \\
11 \text { Lutjanus erythropterus } \\
12 \text { Evynnis cardinalis } \\
13 \text { Rhabdosargus sarba } \\
14 \text { Therapon theraps } \\
15 \text { Trachurus japonicus } \\
16 \text { Nemipterus virgatus } \\
17 \text { Megalaspis cordyla } \\
18 \text { Pneumatophorus japonicus } \\
19 \text { Aluteras monoceros } \\
20 \text { Ephippus orbis } \\
21 \text { Lutjanus vitta } \\
22 \text { Zonichthys nigrofasciata } \\
23 \text { Nemipterus japonicus } \\
24 \text { Ilisha elongata } \\
25 \text { Rachycentron canadum } \\
26 \text { Caranx chrysophry } \\
27 \text { Chiloscyllium plagiosum } \\
28 \text { Pomadasys hasta } \\
29 \text { Polydactylus sextarius } \\
30 \text { Sepia sp. } \\
31 \text { Loligo formosana }\end{array}$ & $\begin{array}{r}7 \\
4 \\
2 \\
2 \\
7 \\
7 \\
3 \\
1 \\
2 \\
9 \\
5 \\
4 \\
4 \\
14 \\
9 \\
9 \\
6 \\
5 \\
5 \\
5 \\
4 \\
4 \\
4 \\
3 \\
2 \\
2 \\
2 \\
2 \\
1 \\
3 \\
3\end{array}$ & $\begin{array}{l}7 \\
4 \\
2 \\
2 \\
6 \\
5 \\
2 \\
1 \\
1 \\
4 \\
2 \\
1 \\
1 \\
2 \\
1 \\
0 \\
0 \\
0 \\
0 \\
0 \\
0 \\
0 \\
0 \\
0 \\
0 \\
0 \\
0 \\
0 \\
0 \\
0 \\
0\end{array}$ & $\begin{array}{c}100 \\
100 \\
100 \\
100 \\
85.7 \\
71.0 \\
67.0 \\
100 \\
50.0 \\
44.4 \\
40.0 \\
25.0 \\
25.0 \\
14.2 \\
11.1 \\
0 \\
0 \\
0 \\
0 \\
0 \\
0 \\
0 \\
0 \\
0 \\
0 \\
0 \\
0 \\
0 \\
0 \\
0 \\
0\end{array}$ & $\begin{array}{l}\mathrm{H} \\
\mathbf{H} \\
\mathbf{H} \\
\mathrm{H}, \mathrm{P} \\
\mathrm{H}\end{array}$ \\
\hline Total & 140 & 41 & 29.3 & \\
\hline
\end{tabular}

H: Hysterothylacium, P: Terranova Cannon Type I 


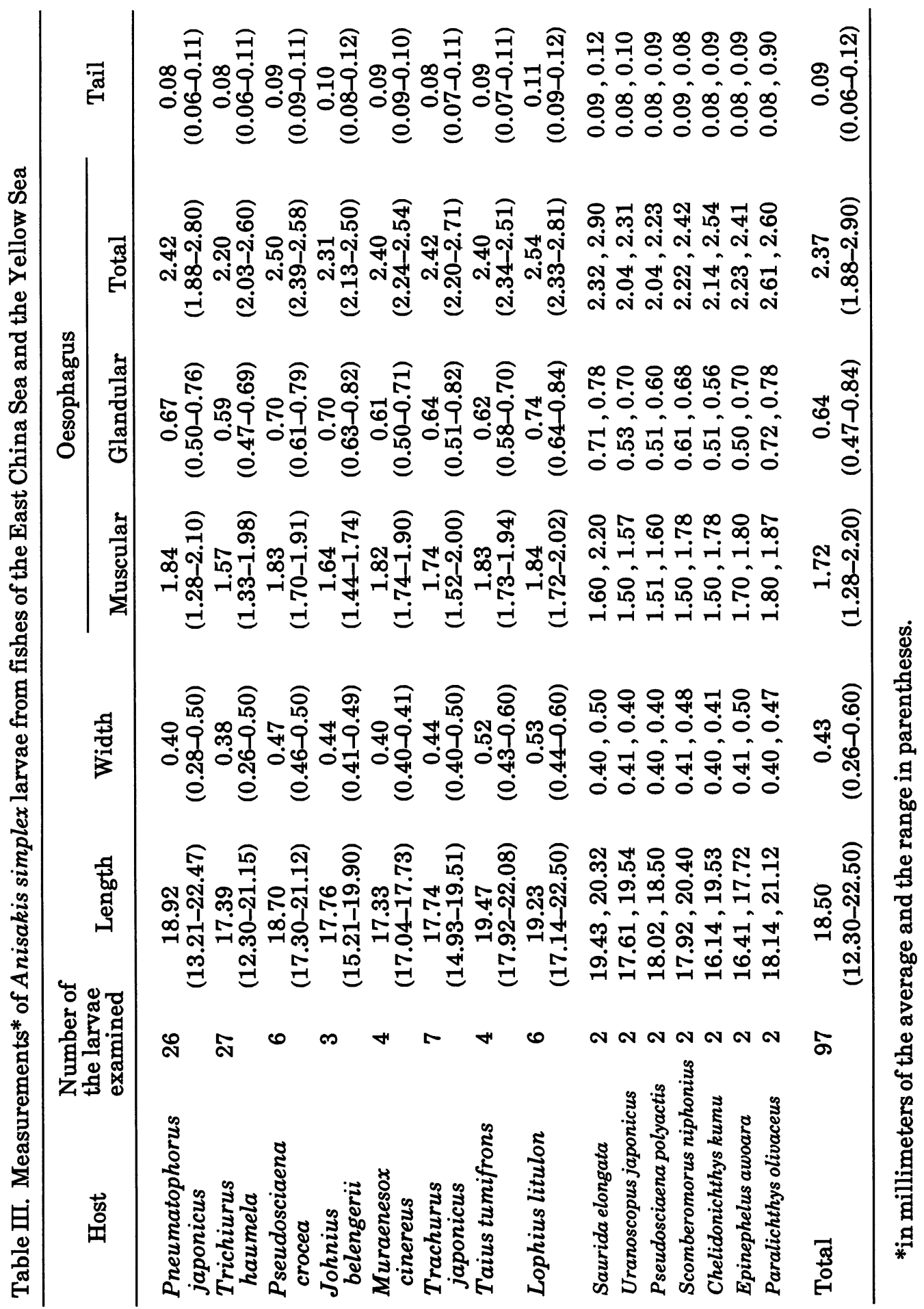


Table IV. Anisakidae larvae from various fishes and squids caught in the East China Sea and the Yellow Sea

\begin{tabular}{|c|c|c|c|c|}
\hline Host & $\begin{array}{l}\text { Number } \\
\text { examined }\end{array}$ & $\begin{array}{l}\text { Number of } \\
\text { fishes and } \\
\text { squids } \\
\text { infected with } \\
\text { Anisakis } \\
\text { simplex } \\
\text { larvae }\end{array}$ & $\begin{array}{l}\text { Infec- } \\
\text { tion } \\
\text { rate } \\
(\%)\end{array}$ & $\begin{array}{l}\text { Anisakidae } \\
\text { larvae of } \\
\text { other than } \\
\text { Anisakis } \\
\text { simplex }\end{array}$ \\
\hline $\begin{array}{l}1 \text { Pneumatophorus japonicus } \\
2 \text { Trichiurus haumela } \\
3 \text { Muraenesox cinereus } \\
4 \text { Saurida elongata } \\
5 \text { Taius tumifrons } \\
6 \text { Uranoscopus japonicus } \\
7 \text { Pseudosciaena polyactis } \\
8 \text { Pseudosciaena crocea } \\
9 \text { Johnius belengerii } \\
10 \text { Lophius litulon } \\
11 \text { Trachurus japonicus } \\
12 \text { Scomberomorus niphonius } \\
13 \text { Ilisha elongata } \\
14 \text { Pagrosomus major } \\
15 \text { Sebastiscus marmoratus } \\
16 \text { Chelidonichthys kumu } \\
17 \text { Branchiostegus argentatus } \\
18 \text { Lepidotrigla microtera } \\
19 \text { Paralichthys olivaceus } \\
20 \text { Pseudorhombus arsius } \\
21 \text { Hoplobrotula armata } \\
22 \text { Navodon modestus } \\
23 \text { Epinephelus awoara } \\
24 \text { Sepia sp. } \\
25 \text { Cynoglossus robustus } \\
26 \text { Pleuronichthys cornutus } \\
27 \text { Nemipterus virgatus } \\
28 \text { Stromateoides argenteus } \\
29 \text { Raja hollandi } \\
30 \text { Priacanthus macracanthus } \\
31 \text { Sphyraena pinguis } \\
32 \text { Katsuwonus pelamis } \\
33 \text { Cleisthenes pinetorum } \\
34 \text { Zebrias zebra } \\
35 \text { Loligo formosana }\end{array}$ & $\begin{array}{r}33 \\
22 \\
6 \\
16 \\
24 \\
7 \\
20 \\
13 \\
12 \\
6 \\
23 \\
23 \\
6 \\
6 \\
5 \\
6 \\
6 \\
6 \\
1 \\
1 \\
1 \\
4 \\
2 \\
20 \\
1 \\
10 \\
6 \\
36 \\
5 \\
5 \\
5 \\
2 \\
1 \\
1 \\
9\end{array}$ & $\begin{array}{r}33 \\
22 \\
6 \\
14 \\
21 \\
6 \\
17 \\
11 \\
10 \\
5 \\
19 \\
18 \\
4 \\
4 \\
3 \\
3 \\
3 \\
2 \\
1 \\
1 \\
1 \\
2 \\
2 \\
2 \\
0 \\
0 \\
0 \\
0 \\
0 \\
0 \\
0 \\
0 \\
0 \\
0 \\
0\end{array}$ & $\begin{array}{c}100 \\
100 \\
100 \\
87.5 \\
87.5 \\
85.7 \\
85.0 \\
84.6 \\
83.3 \\
83.3 \\
82.6 \\
78.2 \\
66.6 \\
66.6 \\
60.0 \\
50.0 \\
50.0 \\
33.3 \\
100 \\
100 \\
100 \\
50.0 \\
100 \\
10.0 \\
0 \\
0 \\
0 \\
0 \\
0 \\
0 \\
0 \\
0 \\
0 \\
0 \\
0\end{array}$ & $\begin{array}{l}\text { H } \\
H, P \\
H \\
H \\
H, R, P \\
\text { H,P } \\
\text { H, R } \\
\text { H, R, P } \\
\text { H } \\
\text { H } \\
\text { H } \\
\text { H } \\
\text { H, R } \\
\text { H } \\
\text { H } \\
\text { H } \\
\text { H } \\
\text { H } \\
\text { H } \\
\text { H }\end{array}$ \\
\hline Total & 350 & 210 & 60.0 & \\
\hline
\end{tabular}

H: Hysterothylacium, P: Terranova Cannon Type I, R: Raphidascaris or Raphidascaroides 
Anisakidae larvae of other than Anisakis simplex were also detected, such as those of several types of Hysterothylacium and Terranova (Cannon Type I) (13). The larvae of Pseudoterranova decipiens, pathogenic to humans, were not found in this survey.

\section{Anisakidae Larvae Found in Marine Fishes and Squids Captured in the East China Sea and the Yellow Sea}

Thirty-five species of marine fishes and squids were investigated for Anisakidae larvae infection. The detected Anisakis simplex larvae were measured and morphologically examined (Table III). The larvae were identified in the way referred to above.

In 24 species of fishes and squids tested, Anisakis simplex larvae infection was confirmed (Table IV). The number of fishes and squids examined was 350 , and the number of those infected with the larvae 210. The infection rate was $60.0 \%$.

Other Anisakidae worms detected consisted of larvae belonging to several types of Raphidascaris or Raphidascaroides, Hysterothylacium, and Terranova (Cannon Type I). Even in this survey, the larvae of Pseudoterranova decipiens were not detected.

\section{DISCUSSION}

The Anisakidae larvae infection is commonly found among fishes and squids in seas throughout the world.

Anisakis simplex larvae are most important among such Anisakidae larvae from a standpoint of preventive medicine, as they are pathogenic to humans and very commonly found in foodstuffs such as marine fishes and squids. Many reports of Anisakis simplex larvae infection in marine fishes and squids have been published in the world, especially in Japan. Such studies, however, have not been published in China, except for one report by Dr. Hsu et al. and two reports by Dr. Sun et al (10-12).

The present study was carried out for the purpose of clarifying the situation of Anisakis infection among the seafishes and squids captured off the coast of China. As a result of this research, the following facts were made clear: (1) Anisakis simplex larvae were detected in many kinds of inshore and offshore fishes in China; (2) the infection rates were $29.3 \%$ in fishes and squids captured 
in the Gulf of Tongking and $60.0 \%$ in those captured in the East China Sea and the Yellow Sea; (3) the infection rates showed considerably high fluctuation among fish species, and (4) the infection was found for the first time in Sepia sp. All of these facts were previously unknown in China.

It is not understood why the infection rate of Anisakis Type I larvae in fishes and squids captured in the Gulf of Tongking is lower than that in the East China Sea and the Yellow Sea. This is a very interesting problem to be solved in the future.

In the countries other than China surrounding the Yellow Sea, the East China Sea or the South China Sea, several reports concerned with Anisakis larvae have been published (14-17). The situations of Anisakis infection in marine fishes described in these reports are very similar from one to another.

Squids belonging to Doryteuthis, Gonatus, Onychoteuthis, Todarodes and others (Suborder: Teuthoidea) have been known to be intermediate hosts of Anisakis simplex. In the present study, the infection was confirmed even in squids belonging to Sepia (Suborder: Sepioidea) for the first time. The fact is very important from the food hygienic point of view, because more squid species than those known before were found to be contaminated with Anisakis simplex larvae.

Anisakiasis has never been found among the Chinese people. Several conditions conducive to human anisakiasis, however, are now present in China. Such conditions are the high infection rates in seafishes and squids in the seas near China, the existence of the custom of eating raw fishes and squids among some Chinese people and the recent importation of the custom of eating Sushi and Sashimi from Japan to China. In these circumstances, it is likely that human cases of anisakiasis will occur in China in the near future.

Hsu et al. (10) reported that such seafishes as Coilia ectines which go up a river at the egg-laying time were contaminated with Anisakis simplex larvae. If this is true, the Chinese people will also have to be careful of the infection through such anadromous fishes, which are also a protein source for them.

Raphidascaris or Raphidascaroides larvae are nonpathogenic to humans, therefore, they are not discussed further in this report. The pathogenicity of Hysterothylacium larvae to humans is still unclear. No human cases of parasitic diseases caused by the larvae have been reported in the world. More work on the larvae will be necessary. Terranova Cannon Type I larvae may belong to another genus, Pseudoterranova, according to Gibson's assertion (18). Though the larva of Pseudoterranova decipiens is known to be pathogenic to humans, it has not been clear whether Terranova Cannon Type I larva is pathogenic to humans or not. 


\section{ACKNOWLEDGEMENTS}

We express our gratitude to the Kanehara Japan-China Medical Research Charitable Trust Foundation for the financial assistance.

\section{REFERENCES}

1. van Thiel, P. H. (1962): Anisakiasis. Parasitology, 52, 16-17.

2. Koyama, T., Kobayashi, A., Kumada, M., Komiya, Y., Oshima, T., Kagei, N., Ishii, T. and Machida, M. (1969): Morphological and taxonomical studies on Anisakidae larvae found in marine fishes and squids. Jpn. J. Parasitol., 33, 73-92 (in Japanese).

3. Hatada, T. (1970): A survey on Anisakidae larvae found in fishes and cephalopods caught in th Seto Inland Sea and the Japan Sea. Bull. Publ. Hlth. Inst. Hyogo Prefec., No. 5, 34-43 (in Japanese).

4. Sakaguchi, Y. and Katamine, D. (1971): Survey of anisakid larvae in marine fishes caught from the East China Sea and the South China Sea. Nettai Igaku, 13, 159-169 (in Japanese).

5. Shiraki, T. (1974): Larval nematodes of Family Anisakidae (Nematoda) in the northern sea of Japan - as a causative agent of eosinophilic phlegmone or granuloma in the human gastro-intestinal tract. Acta Med. Biol., 22, 57-98.

6. Kagei, N., Sano, M., Takahashi, Y., Tamura, Y. and Sakamoto, M. (1978): A case of acute abdominal syndrome caused by Anisakis Type II larva. Jpn. J. Parasitol., 27, 427-431.

7. Fukuda, T., Tongu, Y., Aji, T., Lai, J., Ho, L., Shimono, K. and Inatomi, S. (1982): Anisakidae larvae from some fishes in the Seto Inland Sea. Jpn. J. Parasitol., 31, 171-176 (in Japanese).

8. Fujino, T., Ooiwa, T. and Ishii, Y. (1984): Clinical, epidemiological and morphological studies on $\mathbf{1 5 0}$ cases of acute gastric anisakiasis in Fukuoka Prefecture. Jpn. J. Parasitol., 33, 73-92 (in Japanese).

9. Hasegawa, H., Miyagi, S. and Otsuru, M. (1985): Anisakiasis confirmed by endoscopic examination of the large intestine. Jpn. J. Parasitol.,34, 37-40.

10. Hsu, N., Sun, Z., Tong, Y. and Tao, C. (1978): The biological indicator of the spawning migration of anchovy (Coilia ectines, Jordan et Seale) in Yangtze River. J. Nanking Univ., No. 3, 85-91 (in Chinese).

11. Sun, S., Zhang, Y., Pan, G. and Sun, M. (1986): Preliminary investigation on Anisakis larvae infestation in marine fishes. J. Parasitol. Parasit. Dis., 4, 181-185 (in Chinese).

12. Sun, S., Zhang, Y. and Shen, M. (1987): Scanning electron microscopy on Anisakis Type I third stage larva. Chinese J. Parasitol. Parasit. Dis., 5, 4950 (in Chinese). 
13. Cannon, L. R. G. (1977): Some larval ascaridoids from south-eastern Queensland marine fishes. Int. J. Parasitol., 7, 233-243.

14. Ilahude, H. D., Hadidjaja, P. and Mahfudin, H. (1978): Survey on anisakid larvae in marine fish from fish markets in Jakarta. Southeast Asian J. Trop. Med. Publ. Hlth., 9, 48-50.

15. Hadidjaja, P., Ilahude, H. D., Mahfudin, H., Burhanuddin, and Hutomo, M. (1978): Larvae of Anisakidae in marine fish of coastal waters near Jakarta, Indonesia. Amer. J. Trop. Med. Hyg., 27, 51-54.

16. Chao, D. (1985): Survey of Anisakis larvae in marine fish of Taiwan. Int. J. Zoon., 12, 233-237.

17. Chai, J., Chu, Y. M., Sohn, W. and Lee, S. (1986): Larval Anisakids collected from the yellow corvina in Korea. Korean J. Parasitol., 24, 1-11.

18. Gibson, D. I. (1983): The systematics of ascaridoid nematodes - A current assessment. p.321-338. In A. R. Stone, H. M. Platt and L. F. Khalil (eds.), Concepts in Nematode Systematics. Academic Press, London. 